\title{
RAPESEED GENETIC RESEARCH TO IMPROVE ITS AGRONOMIC PERFORMANCE AND SEED QUALITY
}

\author{
Rakow, G. , Relf-Eckstein, J.A. and Raney, J.P. \\ Agriculture and Agri-Food Canada, Saskatoon Research Centre, \\ 107 Science Place, Saskatoon, SK, S7N OX2 Canada \\ Received: October 10, 2006 \\ Accepted: May 15, 2007
}

\section{SUMMARY}

Rapeseed (canola) is the major Canadian oilseed and average annual production was 6,871,600 metric t for the 10-year period 1996-2005. Brassica napus is the only species grown, and only summer annual forms are cultivated in the short season areas of the western Canadian prairie. About $70 \%$ of the total production is exported, either as seed $(50 \%)$ or oil $(20 \%)$. We utilized inter-specific crosses between $B$. napus and related species to improve the disease resistance and seed quality of $B$. napus. We produced yellow-seed forms of $B$. napus from crosses with B. rapa and B. juncea which have higher seed oil content, and lower meal fiber content to improve the feed value of the meal. We also produced germplasm with high oleic/low linolenic acid content to improve the nutritional value of canola oil as well as its technological qualities for use in the production of solid fats without trans fatty acids. The content of saturated fats in canola oil was reduced to less than $5 \%$ of total fatty acids. Inter-specific methodology was also successful in the development of $B$. juncea mustard as an edible oilseed crop with high yield, disease resistance and seed quality for production in the semiarid regions of the Canadian prairie. This paper will describe the crossing approaches used to develop this germplasm and discuss future research activities for canola improvement.

Key words: Rapeseed (canola), inter-specific crosses, disease resistance, high oleic/low linolenic acid content, glucosinolate content

\section{INTRODUCTION}

Oilseed rape (Brassica napus) is the major oilseed crop in Canada and was grown on 4,629,300 ha annually over the 10-year period 1996-2005 (Canada Grains Council, 2005) resulting in a average annual production of 6,871,600 metric $\mathrm{t}$ for this 10-year period. The major areas of canola production are in western Canada where $99 \%$ of total production occurs. For the 10-year period 1994-2003, about one half of seed produced was exported as seed, $52.3 \%$ of all seed exports

* Corresponding author: e-mail: rakowg@agr.gc.ca 
went to Japan. About one half of the total crop is crushed in Canada. For 2002-03 canola, about $85 \%$ of oil and $99.5 \%$ of meal was exported to the USA. Canola oil is favored over other vegetable oil in the US because of its low saturated fat content of less than $7 \%$ of total fatty acids which allows it to be marketed as a low saturated fat oil. Canola meal is the preferred protein source for dairy cattle feed in California.

Breeding and genetic research at AAFC Saskatoon focuses on quality improvements of the B. napus canola crop (both the oil and meal), and on diversification of production through the development of canola quality types in B. juncea mustard (Rakow and Raney, 2003). The genomic relationships between species in the genus Brassica allow for interspecific transfer of quality traits between species, and the results of this work will be reviewed in this paper.

\section{MATERIALS AND METHODS}

\section{Plant materials}

Interspecific crosses between plants of different species were performed on greenhouse grown plants through emasculation of flowers at the bud stage and pollination of stigmas with fresh pollen from the male parent. We used standard "bud pollination techniques", allowing the developing interspecific embryos to mature on the female parent. No embryo rescue techniques were applied (Rashid et al., 1994). Interspecific hybrid plants were grown and backcrossed to the target species to produce and select plants with the desired introgressed quality traits. Several backcrosses had to be made to recover a true breeding line that exhibited the new trait in a genetically stable fashion. The agronomic performance and seed quality attributes of newly developed lines was evaluated in field nurseries and replicated yield tests at the AAFC Research Farm at Saskatoon, Canada.

\section{Seed chemical analyses}

The fatty acid composition of the seed oil was determined by the method of Thies (1971), except that gas chromatography of the methyl esters was performed with a supelcowax 10 fused silica capillary column at $210^{\circ} \mathrm{C}$ using hydrogen as the carrier gas. The glucosinolate content of seed meal was determined by the gas chromatographic method of Thies (1980). Glucosinolates were extracted with 65\% methanol, trimethylsilylation was carried out according to Landerouin et al. (1987) and gas chromatography of trimethylsilyl derivatives was on J \& W DB-1 fused silica capillary column (Sosulski et al., 1984) at $280^{\circ} \mathrm{C}$ using hydrogen as a carrier gas. 


\section{RESULTS AND DISCUSSION}

\section{Development of yellow-seeded Brassica napus}

The high-fiber content of canola meal limits inclusion rates for canola meal into high protein animal feed, especially for pigs and poultry. The high fiber content is a result of the small seed size of canola compared with soybean. It has been known for some time that meal from yellow-seeded lines has much lower meal fiber contents than meal from black-seeded lines due to their thinner seed coat. The yellow seed trait is well established in B. rapa, B. juncea and B. carinata, while no yellowseeded forms exist in natural populations of $B$. napus. However, true breeding yellow-seeded forms of $B$. napus have now been developed through interspecific crosses with related yellow-seeded Brassica species. The productivity (yield), disease resistance and seed quality (oil and protein content) of new, yellow-seeded, "canola-quality" lines of the AAFC Saskatoon Research Centre is at least comparable, and in certain aspects, superior, to that of standard black-seeded B. napus cultivars (Table 1).

The acid deterent digestion method was used to measure fiber contents in black versus yellow-seeded lines. The acid detergent fiber content of meal from blackseeded B. napus seed was $13.6 \%$ on a dry meal basis, as compared with $8.2 \%$ for meal from the yellow-seeded line, a reduction of $40 \%$. The greatest reduction was observed in acid detergent lignin which was reduced from $5.4 \%$ to $1.3 \%$, a reduction of $76 \%$. There was also a reduction in neutral detergent fiber and cellulose contents while hemicellulose contents were actually higher in meal from yellow seeds. Similar observations were made in seed meals from brown versus yellow-seeded $B$. rapa and B. juncea.

Table 1: Agronomic and quality performance of yellow- and black-seeded Brassica napus canola

\begin{tabular}{|c|c|c|c|c|c|c|c|}
\hline \multirow{2}{*}{ Lines } & \multirow{2}{*}{$\begin{array}{l}\text { Yield } \\
\text { (kg/ha) }\end{array}$} & \multirow{2}{*}{$\begin{array}{l}\text { Oil } \\
(\%)\end{array}$} & \multirow{2}{*}{$\begin{array}{l}\text { Protein } \\
\text { (\% meal) }\end{array}$} & \multirow{2}{*}{$\begin{array}{c}\text { GSL } \\
(\mu \mathrm{mol} / \mathrm{g})\end{array}$} & \multicolumn{3}{|c|}{ Fiber (\% dry meal) } \\
\hline & & & & & ADL & ADF & NDF \\
\hline YN01-429 & 2030 & 49.1 & 46.9 & 12.9 & 1.3 & 8.2 & 14.9 \\
\hline 46A65/Q2 & 1890 & 45.8 & 49.0 & 17.7 & 5.4 & 13.6 & 19.1 \\
\hline \multicolumn{8}{|l|}{ Diff } \\
\hline$(\mathrm{Y}-\mathrm{B})$ & +140 & +3.3 & -2.1 & -4.8 & -4.1 & -5.4 & -4.2 \\
\hline Sig (p) & ns & $<0.01$ & $<0.05$ & $<0.01$ & $<0.01$ & $<0.01$ & $<0.01$ \\
\hline Station yrs & 6 & 6 & 5 & 4 & 4 & 4 & 4 \\
\hline
\end{tabular}

Oil by NMR, protein by Leco combustion, GSL (total glucosinolates) by gas chromatography, fiber by Ankom 200 Fiber Analyzer, ADL=acid detergent lignin, $\mathrm{ADF}=$ acid detergent fiber (cellulose+lignin), $\mathrm{NDF}=$ neutral detergent fiber (hemicellulose + cellulose +lignin + pectin). 


\section{Fatty acid composition of Brassica oilseeds}

The fatty acid composition of the commercial Canadian Brassica napus canola crop in 2002 was typical for this species and similar to what was observed in the past over many years (Table 2). Brassica napus canola oil has high concentrations of oleic acid (about 60\%), and contains moderate levels of linoleic (about 20\%) and linolenic acid (about 10\%). This fatty acid composition of a vegetable oil is considered ideal for human nutrition by many nutritionists, and superior to that of many other plant oils. Canola oil also has the lowest saturated fatty acid content of any vegetable oil of about $7 \%$ of total fatty acids. A low saturated fat content of less than $7 \%$ is critical for labelling canola oil as a low saturated fat product in the USA, the major customer of Canadian canola oil.

Table 2: Fatty acid composition of Brassica oilseeds

\begin{tabular}{|c|c|c|c|c|c|c|c|}
\hline \multirow{2}{*}{ Species } & \multirow{2}{*}{ Variety and line } & \multicolumn{6}{|c|}{ Fatty acid composition (\% of total) } \\
\hline & & C16:0 & C18:0 & C18:1 & C18:2 & C18:3 & Total Sat. \\
\hline \multirow[t]{2}{*}{ B. napus } & Canada com. & 3.9 & 1.9 & 60.6 & 19.1 & 10.6 & 7.0 \\
\hline & AC Excel & 3.6 & 2.0 & 65.1 & 16.6 & 9.2 & 6.8 \\
\hline B. juncea & J90-4253 & 4.3 & 2.1 & 43.6 & 34.6 & 11.9 & 7.6 \\
\hline \multicolumn{8}{|c|}{ Modified lines } \\
\hline \multirow[t]{3}{*}{ B. napus } & 5314-22 & 3.9 & 2.0 & 77.8 & 8.7 & 2.8 & 7.4 \\
\hline & $5906-6$ & 2.4 & 1.1 & 55.0 & 29.3 & 8.5 & 4.3 \\
\hline & $5908-31$ & 3.1 & 1.2 & 67.7 & 16.7 & 7.8 & 5.3 \\
\hline B. juncea & J00-6717 & 3.4 & 2.8 & 63.8 & 16.0 & 10.6 & 7.2 \\
\hline
\end{tabular}

Canada com. = Canada commerical B. napus canola crop 2002

Canadian Grain Commission harvest survey; AC

Excel and experimental lines $=$ Saskatoon Field Tests

Brassica juncea is a potential oilseed crop for the semiarid Canadian prairies and many other countries of the world, such as China, India and others, because of its better adaptation to dry and hot climates compared with $B$. napus. The oil of zero erucic acid cultivars and lines is low in oleic acid (about 45\%) and high in linoleic acid (about 35\%) in comparison to B. napus oil; it also has elevated saturated fat contents of $7.5 \%$.

Even though the fatty acid composition of B. napus is ideal from a nutritional standpoint, there are segments of the vegetable oilseed market that require a more stable oil high in oleic and low in linolenic acid, for high temperature applications such as frying. We developed a novel $B$. napus line with $>75 \%$ oleic acid and $<3 \%$ linolenic acid from crosses of mutant lines. Many breeding groups have developed similar quality lines utilizing mutagenesis. The leading firms in this area in Canada are Dow AgroSciences and Cargill. Several patents exist which protect various types of fatty acid profiles of oleic and linolenic acid (linoleic acid), and in certain cases in combinations with claims for low saturated fat content. Patent protection of plant lines is possible in the USA, but not in Canada. Patent protection of plant lines hinders progress in this area in that it restricts the free flow of germplasm for further 
improvements of canola oil qualty. It is expected that about one half or more of the total canola acreage in Canada could be planted to high oleic/low linolenic acid cultivars in the future.

We successfully developed low saturated fat $B$. napus from interspecific crosses with $B$. rapa and through mutant induction. Line 5906-6 had a total saturated fat content of only $4.3 \%$ in combination with reduced oleic and elevated linoleic acid contents. Line 5908-31 had a total saturated fat content of $5.3 \%$, but with high oleic $(67.7 \%)$ and low linoleic acid (16.7\%) contents.

Industry consultations during the development of $B$. juncea as a potentially new edible oilseed species for Canada concluded that the "wild-type" fatty acid composition of zero erucic acid B. juncea with only about $45 \%$ oleic acid and about $35 \%$ linoleic acid was unacceptable for a "canola-quality" oil. An increase in oleic acid to a minimum level of $55 \%$ (an increase by at least $10 \%$ ) with a corresponding reduction in linoleic acid would be required to make the oil of $B$. juncea acceptable to Canadian oilseed crushers. We attempted this modification through an interspecific cross with the low linolenic acid B. napus, followed by backcrosses to B. juncea in combination with reselection of plants with $B$. napus - like fatty acid composition before carrying out the next backcross. Five backcrosses to $B$. juncea were required to establish true breeding $B$. juncea plants with 36 chromosomes and normal meiotic behavior (18 bivalents) which expressed the typical fatty acid profile of $B$. napus. The line J00-6717 is an example of this research containing $63.8 \%$ oleic, $16.0 \%$ linoleic and $10.6 \%$ linolenic acid in its seed oil (Table 2 ). This line had a total saturated fat content of $7.2 \%$

\section{Glucosinolate content of Brassica oilseeds}

The average total glucosinolate content of the 2005 Canadian B. napus canola crop was $9 \mu \mathrm{mol} / \mathrm{g}$ seed at $8.5 \%$ moisture level, making Canadian canola a good source of high quality, high protein animal feed. Total glucosinolate content in $B$. napus seed consists of about $60 \%$ alkenyl glucosinolates and $40 \%$ indolyl glucosinolates (Table 3). The dominating alkenyl glucosinolate is 2-hydroxy-3-butenyl glucosinolate. This indicates strong hydroxylation capacity in $B$. napus.

Table 3: Glucosinolate content of Brassica oilseeds

\begin{tabular}{llcccccc}
\hline \multirow{2}{*}{\begin{tabular}{l} 
Species \\
\cline { 3 - 7 }
\end{tabular}} & \multicolumn{2}{c}{ Variety and line } & \multicolumn{7}{c}{$\mu \mathrm{mol} / \mathrm{g}$ seed dry } \\
\cline { 3 - 8 } B. napus & AC Excel & - & But & Pent & HoBu & HoPe & Tot I \\
B. napus & TO97-3233 & - & 0.2 & 0.0 & 0.3 & 0.0 & 3.6 \\
& N01-1761 & - & 0.0 & 0.0 & 0.1 & 0.0 & 1.1 \\
B. juncea & AC Vulcan & 105.0 & 3.7 & 0.0 & 0.1 & 0.1 & 0.6 \\
& J90-4316 & 0.8 & 14.7 & 1.4 & 1.2 & 0.0 & 3.6 \\
& J00-6866 & 0.1 & 1.9 & 0.1 & 0.1 & 0.0 & 3.3 \\
\hline
\end{tabular}

Variety and experimental lines Saskatoon field tests. 
It has been demonstrated that further reduction of glucosinolates in canola or their complete elimination will further increase the feed value of canola meal. "Zero" $(<1.0 \mu \mathrm{mol} / \mathrm{g}$ seed) aliphatic glucosinolate lines of $B$. napus were identified in segregating generations of the double interspecific cross between yellow-seeded B. napus with B. rapa AC Parkland (yellow-seeded) and B. alboglabra (yellowbrown seeded). The zero alkenyl glucosinolate lines were then crossed with yellowseeded, low linolenic acid B. napus and the cross pedigree selected. The line TO973233 was field evaluated in a yield test at Saskatoon in 1999 and had a total aliphatic glucosinolate content of $0.5 \mu \mathrm{mol} / \mathrm{g}$ seed, $3.6 \mu \mathrm{mol} / \mathrm{g}$ seed indole glucosinolates for a total glucosinolate content of $4.1 \mu \mathrm{mol} / \mathrm{g}$ seed. The seed was yellowbrown in color and had a linolenic acid content of about 3\% (data not shown).

The next step was a further reduction of indole glucosinolate contents to lowest possible concentrations. A "zero" $(\sim 1.0 \mu \mathrm{mol} / \mathrm{g}$ seed $)$ indole glucosinolate $B$. rapa selection, based on yellow sarson crosses, was crossed with the "zero" aliphatic glucosinolate $B$. napus line to introgress the low indole glucosinolate trait from $B$. rapa into $B$. napus. Two backcrosses were made to $B$. napus to reconstitute a true breeding $B$. napus plant. The line N01-1761, which was field evaluated at Saskatoon in a 2-replicate row nursery in 2001, had a total aliphatic glucosinolate content of $0.1 \mu \mathrm{mol} / \mathrm{g}$ seed, $1.1 \mu \mathrm{mol}$ of indole glucosinoaltes for a total glucosinolate content of $1.2 \mu \mathrm{mol} / \mathrm{g}$ seed.

Standard condiment mustard cultivars such as AC Vulcan contain high concentrations of allyl glucosinolate in their seed (Table 3). The first step in meal quality improvement was the elimination of allyl glucosinolate from B. juncea seed (Love et al., 1990). The interspecific-derived line J90-4316 contained less than $1.0 \mu \mathrm{mol}$ of allyl glucosinolate and the 3-butenyl glucosinolate content was about $15 \mu \mathrm{mol} / \mathrm{g}$ seed. The line contained low concentrations of indole glucosinolate and it had a total glucosinolate content of about $22 \mu \mathrm{mol} / \mathrm{g}$ seed.

Progeny from crosses and backcrosses with $B$. napus described above, which led to the isolation of $B$. juncea lines with $B$. napus fatty acid composition (line J00-6717, Table 2), were also selected for further reduced glucosinolate content. These selections resulted in the isolation of very low alkenyl and total glucosinolate content lines. Line J00-6866 contained only $2.2 \mu \mathrm{mol} / \mathrm{g}$ seed of alkenyl glucosinolates, $3.3 \mu \mathrm{mol} / \mathrm{g}$ seed of indole glucosinolates for a total glucosinolate content of $5.5 \mu \mathrm{mol} / \mathrm{g}$ seed.

\section{CONCLUSIONS}

Our goal is to develop true breeding, yellow-seeded cultivars of B. napus that are high yielding, resistant to diseases and have high oil and protein contents, and to convert the total Canadian canola acreage to yellow-seeded cultivars. Yellowseeded cultivars will have an inherently higher seed oil content of 1 to $2 \%$ over black-seeded cultivars. The introduction of yellow-seeded cultivars will require 
identity preserved production of guarantee improved meal quality to the feed industry. Further reductions or the complete elimination of glucosinolates from canola seed will further improve the feed value of canola meal.

There is an increasing demand, in Canada and the USA, for temperature stable vegetable oils which will require the breeding of competitive high-yielding cultivars with high oleic-low linolenic acid contents. Such oil is of great importance for the production of solid fats in that it requires little or no hydrogenation thus significantly reducing or completely eliminating the formation of trans fatty acids. About one half of the total Canadian canola acreage could be planted to these cultivars in the future to meet market demand. For North America (USA) the breeding of cultivars with low contents of saturated fats is of importance. The total saturated fat content must be $<7 \%$ to label products as "low in saturated fat." The classification as "zero saturated fat" is possible for products containing $<3.5 \%$ saturated fatty acids.

The establishment of $B$. juncea canola will diversify canola production on the Canadian prairie, potentially increasing production and contribute to more sustainable oilseed production in Canada.

\title{
REFERENCES
}

Canada Grains Council, 2005. Field Crop Reporting Series, Catalogue 22-002, Statistics Canada.

Landerouion, A., Quinsac, A. and Ribaillier, 1987. Optimization of silylation reactions to desulpho - glucosinolates before gas chromatography. World Crops: Production, Utilization, Description. Chapter 13: 26-37.

Love, H.K., Rakow, G., Raney, J.P. and Downey, R.K., 1990. Development of low glucosinolate mustard. Can. J. Plant Sci. 70: 419-424.

Rakow, G. and Raney, J.P., 2003. Present status and future perspectives of breeding for seed quality in Brassica oilseed crops. Proc. $11^{\text {th }}$ Int. Rapeseed Cong., Copenhagen, Denmark. Vol. 1: pp. 181-185.

Rashid, A., Rakow, G. and Downey, R.K., 1994. Development of yellow-seeded Brassica napus through interspecific crosses. Plant Breeding 112: 127-134.

Sosulski, F.W. and Dabrowski, K.J., 1984. Determination of glucosinolates in canola meal and protein products by desulfation and capillary gas liquid chromatography. J. Agr. and Food Chem. 32: 1172-1174.

Thies, W., 1971. Schnelle und einfache Analysen der Fettsäurezusammensetzung in einzelnen Raps-Kotyledonen. Z. Pflanzenzüchtg. 65: 181-202.

Thies, W., 1980. Analysis of glucosinolates via "on-column" desulfation. Proc. Symp. "Analytical Chemistry of Rapeseed and its Products." Winnipeg, Canada, pp. 66-71.

\section{INVESTIGACIONES GENÉTICAS DE COLZA CON EL FIN DE MEJORAMIENTO DE SUS PROPIEDADES AGRONÓMICAS Y CALIDAD DE SEMILLA}

\author{
RESUMEN
}

La colza (canola) es el principal cultivo oleaginoso de Canadá cuya producción anual era 6.871 .600 de toneladas métricas durante el período de 10 años, desde 1996 hasta 2005. Brassica napus es la única especie que se cul- 
tiva, y sólo las formas anuales estivales se cultivan en las regiones con corto período de vegetación en la pradera canadiense occidental. Alrededor de $70 \%$ de la producción total se exporta, sea en forma de semilla (50\%) o aceite $(20 \%)$. Nosotros hemos utilizado los cruzamientos interespecies de B. napus y de las especies afines, para mejorar la resistencia a enfermedades y la calidad de la semilla en $B$. napus. Fue producida la forma $B$. napus con la semilla amarilla del cruzamiento de B. rapa y B. juncea. Esta forma tuvo el contenido incrementado de aceite en la semilla y bajo contenido de fibras en la tortilla, lo que mejoró el valor nutritivo de la tortilla como forraje. También fue producida la germoplasma con alto contenido del ácido oleico y bajo contenido del ácido linólico, para el mejoramiento del valor nutritivo del aceite de colza, tanto como de su calidad tecnológica para la utilización en la produccin de grasas sólidas sin ácidos transgrasos. El contenido de las grasas saturadas en el aceite de colza queda reducida en menos de $5 \%$ de ácidos grasos totales. La metodología de interspecies también se mostró exitosa en el desarrollo de $B$. juncea de mostaza como cultivo oleaginoso comestible con alto rendimiento, resistencia a enfermedades y calidad de semilla que puede cultivarse con éxito en las zonas semiáridas de la pradera canadiense. En el trabajo se describen los acercamientos al cruzamiento, utilizados en el desarrollo de esta germoplasma, y se consideran las actividades investigadoras adicionales, orientadas hacia el adelanto de colza.

\section{RECHERCHE GÉNÉTIQUE SUR LE CANOLA POUR AMÉLIORER SES PERFORMANCES AGRONOMIQUES ET LA QUALITÉ DES GRAINES}

\section{RÉSUMÉ}

Le colza (canola) est la principale culture oléagineuse du Canada, la production annuelle moyenne était de 6, 871,600 tonnes métriques pour la période de dix ans comprise entre 1996 et 2005. Le Brassica napus est la seule espèce cultivée et seules les formes annuelles estivales sont cultivées dans des régions ayant une courte période de végétation dans la prairie occidentale du Canada. Environ $70 \%$ de la production totale est exportée soit sous forme de graines $(50 \%)$ soit sous forme d'huile $(20 \%)$. Nous avons utilisé le croisement interspécifique $B$. napus et espèces analogues pour améliorer la résistance à la maladie et la qualité des graines de $B$. napus. La forme $B$. napus à graines jaunes a été produite par le croisement de B. rapa et $B$. Juncea. Cette forme avait une augmentation du contenu d'huile dans la graine et un contenu réduit de fibres ce qui a amélioré la valeur alimentaire de la farine. Nous avons aussi produit un plasma germinatif avec un contenu élevé d'acide oléique et un niveau réduit d'acide linoléique pour améliorer la valeur alimentaire de l'huile de colza ainsi que sa qualité technologique pour l'utilisation dans la production de gras solides sans acides gras trans. Le contenu de gras saturés dans l'huile de canola a été diminué à moins de $5 \%$ du total des acides gras. La méthodologie interspécifique s'est aussi montrée efficace pour le développement de la moutarde $B$. juncea en tant que culture oléagineuse comestible à grand rendement, pour la résistance à la maladie et pour la qualité de la graine pouvant être cultivée avec succès dans les régions semi-arides de la prairie canadienne. Cet article décrit les méthodes de croisement utilisées dans le développement de ce plasma germinatif et observe les activités de recherche ultérieures orientés vers l'amélioration du canola. 